УДК 004.085

\author{
I. В. Горбов ${ }^{1}$ А. А. Крючин ${ }^{1}$, А. Ю. Манько, \\ О. І. Томмачов ${ }^{2}$ В. В. КурАюков ${ }^{2}$ Ю. А. САомінський ${ }^{2}$ \\ ${ }^{1}$ Інститут проблем реєстрації інформації НАН України \\ вул. М. Шпака, 2, 03113 Київ, Україна \\ ${ }^{2}$ Інститут органічної хімії НАН України \\ вул. Мурманська, 5, 02660 Київ, Україна
}

\title{
Вплив термічного відпалу на оптичні властивості тонких композитних пмівок
}

\begin{abstract}
Методом центрифугування було отримано композитні плівки органічний барвник - полімер і досліджено вплив термічного відпалу на їхні оптичні властивості. Показано, що підвищення температури термообробки призводить до зниження кількості органічного компонента та структурної перебудови поверхні барвника разом з його структурним упорядкуванням, що призводять до одночасного зменшення інтенсивності поглинання, зменшення товщчини плівки та збільщення показника заломлення.
\end{abstract}

Ключові слова: оптичний запис, лазерна термолітографія, реєструвальне середовище, композитна плівка, органічний барвник.

\section{Вступ}

Основою виготовлення нанорозмірних об'єктів та оптичного запису інформації є лазерна обробка шару фоторезисту чи іншого фоточутливого матеріалу 3 наступним його травленням або з безпосереднім використанням отриманого рельєфу. Для експозиції резистивної плівки можна використовувати як оптичний пучок, так і пучок електронів. Проте електронно-променеві методи вимагають глибокого вакууму та дорогого устаткування. Тому переваги віддаються оптичним методам як більш технологічним і дешевим. Разом з тим використання оптичних методів не вимагає великих зусиль і затрат. Проте для роботи з нанотехнологіями та надщільного запису інформації необхідно створювати об'єкти з характерними розмірами близько 100 нм. Використання оптичної системи 3 максимально можливою числовою апертурою NA $\approx 1$ та довжиною хвилі 405 нм створить світлову пляму діаметром 480 нм, що значно перевищує необхідне значення. Так як швидкість хімічної реакції у фоторезисті пропорційна інтенсивності світла, а швидкість травлення пропорційна кількості молекул, що прореагували, то ширина пітів буде

(C) І. В. Горбов, А. А. Крючин, Д. Ю. Манько, О. І. Толмачов, В. В. Курдюков, Ю. Л. Сломінський 
фактично такою ж як ширина світлової плями i, як наслідок, подібна технологія не може бути використана для нанотехнологій. Попередні експериментальні дослідження такого методу показали, що мінімальна ширина пітів, отриманих лазерним променем з довжиною хвилі 405 нм і сфокусованого об'єктивом з числовою апертурою 0,85 , становить 550 нм [1].

Одним із перспективних підходів для подальшого розвитку оптичних нанотехнологій є лазерна термолітографія, що також відомо як фототермічний запис, при якому під впливом лазерного опромінення відбувається нагрів реєструвального шару та його фазове перетворення [2]. Такий метод дозволяє здолати дифракційну межу та робить можливим використання лазерів 3 довжиною хвиль видимого діапазону для отримання наноструктур, що суттєво знижує вартість відповідного обладнання.

Основною вимогою для здійснення термолітографічного запису даних є використання реєструвальних матеріалів з пороговими властивостями. В якості таких матеріалів можуть використовуватися тонкі композитні плівки на базі полімерних сполук з додаванням сенсибілізуючих домішок. Як полімерну матрицю найчастіше використовують органічні фоторезисти (ФР), поліметилметакрилат (ПММА), поліетилен (ПЕ), політетрофторетилен (ПТФЕ) та ін. [3-5]. Для сенсибілізації можуть використовуватись як метали, так і органічні барвники, що дозволяє отримати плівки з необхідними пороговими властивостями та здійснити термолітографічний запис [6-8]. Наприклад, на тонких плівках $\mathrm{Co}(\mathrm{L})_{2}$ було отримано піти діаметром 300-500 нм за допомогою лазерного променю 3 довжиною хвилі 405 нм, що був сфокусований лінзою з числовою апертурою 0,9 [3]. Кращі результати було отримано в плівках ПММА, що були сенсибілізовані органічними барвниками (спіропіранами та мероціанами) [9]. За допомогою лазерного опромінення $з$ довжиною хвилі 404 нм було отримано піти діаметром 160-300 нм [9].

Необхідно зауважити, що при схожості умов запису в наведених прикладах отримані піти суттєво відрізняються, що зумовлено саме характеристиками реєструвального середовища. Таким чином, однією з актуальних задач термолітографії $\epsilon$ створення відповідних реєструвальних середовищ, дослідження їхніх характерристик і визначення оптимальних режимів запису. Для досягнення цієї мети пропонується використання органічних барвників, що є дуже привабливим матеріалом для термолітографії і довготермінового зберігання інформації.

\section{Виготовмення зразків}

Одним із основних факторів, що визначає розмір отриманих у процесі лазерного запису пітів, $\epsilon$ сукупність оптичних і теплових характеристик реєструвального середовища, які мають задовольняти суперечливим вимогам, а саме: мати велике оптичне поглинання та відбиття, а також малу теплопровідність та теплоємність. Якщо першим вимогам найкраще задовольняють метали, то останнім - органічні матеріали, тому виробити з природних однокомпонентних матеріалів середовища 3 потрібними параметрами неможливо. Було розроблено багатокомпонентні тонкоплівкові матеріали, як композитні, так і тверді розчини, в яких полімерна матриця задає потрібні термофізичні властивості, а наповнювач - оптичні параметри. 
На даний час для оптичного запису широко застосовуються напівпровідникові лазери 3 довжиною хвилі 405 нм. Тому для проведення експериментального дослідження впливу термічного відпалу на зміну оптичних параметрів композитних плівок було виготовлено ряд зразків, які інтенсивно поглинають світло в області 390-410 нм, а саме - зразки тонких плівок на основі нульметинмероціанінів похідних пірану та дигідропіридину, основ $\alpha$-ціано- та 4-амінозаміщених стирилів $[4,8]$. За матрицю використовували позитивний фоторезист $(\Phi \mathrm{P})$, а за розчинник - тетрафторпропанол (ТФП) та діізобутилкетон (ДІБК). У табл. 1 наведено основні дані про основні синтезовані зразки з різними матрицями та органічними барвниками.

Таблиця 1. Основні дані по типовим синтезованим зразкам на базі органічних барвників

\begin{tabular}{|c|c|c|c|c|}
\hline Зразок & $\begin{array}{c}T \text { розкладу } \\
\text { барвника, }{ }^{\circ} \mathrm{C}\end{array}$ & $\begin{array}{c}\text { Максимум } \\
\text { поглинання, нм }\end{array}$ & $\begin{array}{c}\text { Концентрація, } \\
\% \\
\end{array}$ & Матриця \\
\hline "KS-51 & 150 & 381 & 0,9 & $\overline{\overline{\Phi P}}$ \\
\hline KS-69 & \multirow[t]{2}{*}{125} & \multirow[t]{2}{*}{393} & 1,5 & ТФП* \\
\hline KS-70 & & & 1,5 & ДІБК* \\
\hline KS-65 & 150 & 390 & 1,5 & \multirow[t]{3}{*}{$\Phi P$} \\
\hline KT-11 & $>250$ & 400 & 1 & \\
\hline KT-12 & $>250$ & 400 & 1 & \\
\hline K7-1 & $>281$ & 437 & 2 & ТФП* \\
\hline
\end{tabular}

*плівка барвника

За матрицю ми використовували позитивний органічний фоторезист Shipley 1805 , який широко вживаний в мікроелектроніці та в системах мастерінгу оптичних дисків [10]. Вибір цього середовища також був обумовлений тим, що він здатен поглинати світло з довжиною хвилі 405 нм, а також крізь вікна у цьому фоторезисті може проводитися йонно-променеве травлення підкладок оптичних носіїв 3 метою створення мікрорельєфних структур на їхній поверхні.

Плівки наносилися на центрифузі з частотою обертання близько 2800 об./хв. Після нанесення плівки, відповідно до технології нанесення обраного фоторезисту, зразки відпалювалися при температурі $90{ }^{\circ} \mathrm{C}$. Після першої серії досліджень 3 метою видалення залишків розчинника зразки додатково відпалювалися протягом 2 год. при температурі $140{ }^{\circ} \mathrm{C}$. Товщина композитної плівки складала 50-150 нм, що було достатньо для здійснення процесу плазмохімічного травлення. Перед поливом зразки були ретельно очищені від хімічних залишків. Товщина плівок і коефіцієнт їхнього заломлення визначалися за допомогою розв'язку оберненої задачі еліпсоміетрії. Еліпсометричні параметри визначалися за допомогою методу нульової еліпсометрії, використовуючи лазерний еліпсометр ЛЕФ 3М-1, що працює на довжині хвилі $\lambda=632,8$ нм [11]. Обернена задача еліпсометрії була розв'язана за допомогою методу оптимізації Хука-Дживса [12] в моделі тонка плівка - діелектрична підкладка. Кут падіння поляризованого світла під час проведення експерименту варіювався в межах 45-58 . Крім того, оптичні властивості, в тому числі й еліпсометричні, $є$ тими фундаментальними властивостями, які близько пов'язані із структурними особливостями й атомно-електронною будовою самого матеріалу [13]. 


\section{Експериментальні досліАження та обговорення результатів}

На першому етапі було проведено дослідження спектральних характеристик виготовлених композитних плівок і їхніх залежностей від температури відпалу (рис. 1). 3 рисунка видно, що найкращі поглинальні характеристики на довжині хвилі 405 нм притаманні плівкам КT-11, KT-12 і KS-65, максимум поглинання яких відбувається на довжині хвилі 400 нм, а іiі абсолютна величина складає $\sim 70$ \%. Необхідно відзначити, що дані зразки було виготовлено на базі ФР, який не відзначається такими властивостями (рис. 1). На довжині хвилі 470 нм спостерігається ще одна смуга поглинання з максимумом, яка зумовлена власною характеристикою ФР. Набагато гіршими поглинальними властивостями володіють зразки KS-69 та KS-70, які було виготовлено на основі матриць ТФП і ДІБК відповідно (табл. 1). Таким чином, можна стверджувати, що вибір ФР як матриці для реєструвального середовища є оптимальним. Необхідно відзначити відносно широкий спектр поглинання плівки К7-1 на основі азо-комплекса [7].

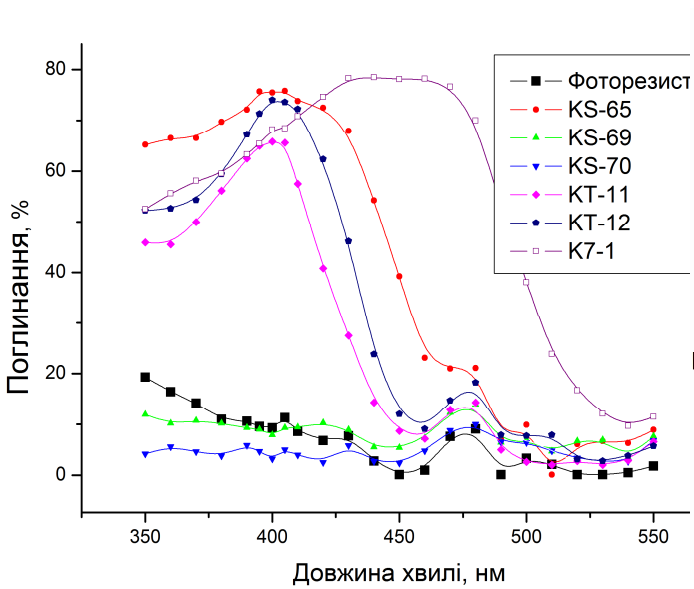

a)

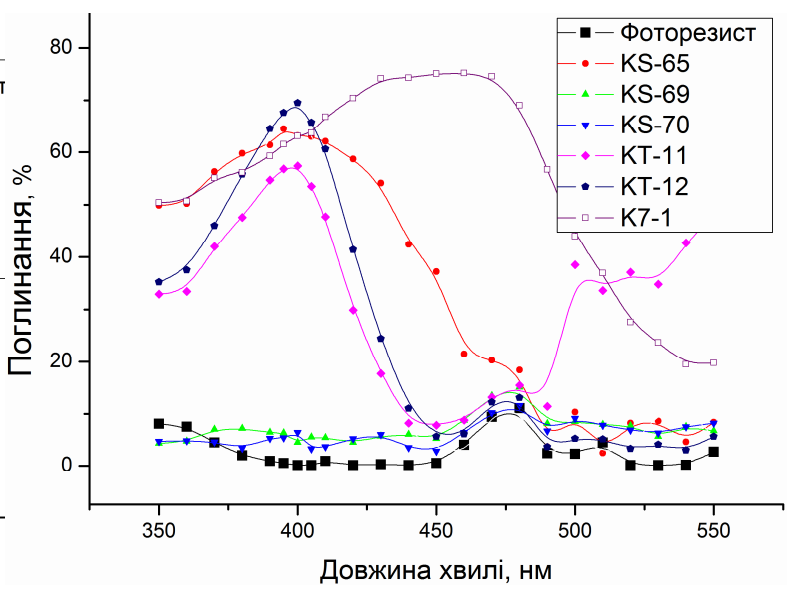

б)

Рис. 1. Спектральні залежності оптичного поглинання для тонких композитних плівок після їхнього нанесення (а) та після відпалу при температурі 140 C (б)

Після проведення термічної обробки оптичні спектри поглинання зазнали суттєвих змін, що необхідно враховувати при моделюванні процесу термолітографічного лазерного запису. Так, смуги поглинання для всіх зразків стали менш інтенсивними. Слід відмітити особливості оптичного поглинання зразків КТ-11, КТ-12 та К7-1, які зазнали найменших змін після термічного відпалу. Таким чином, подальші еліпсометричні дослідження було вирішено проводити для зразків на базі фоторезисту.

На рис. 2 представлено дані еліпсометричних досліджень плівки фоторезисту, нанесеної на скляну підкладку. 3 рисунку видно, що кутові залежності азимуту відновленої лінійної поляризації $\Psi$ і різниці фаз між $p$ - і $s$-поляризованого світла $\Delta$ не змінюють характер своєї поведінки при проведені термічного відпалу при температурі $90{ }^{\circ} \mathrm{C}$, яка є стандартною для процесу нанесення даного фоторезисту. Криві $\Psi$ для випадків щойно виготовленого зразка і відпаленого при температурі 
$90{ }^{\circ} \mathrm{C}$ майжне невідрізнені. Сутєва різниця з щойновиготовленим зразком спостерігається після відпалу при температурі $140{ }^{\circ} \mathrm{C}$. Потрібно відмітити, що крива $\Psi$ може бути апроксимована за допомогою лінійної залежності $y=k \cdot x+b$. При цьому крива $\Psi$ може бути апроксимована за допомогою поліному другого порядку. 3 результатів еліпсометричних досліджень можна також зробити висновок, що шорсткість поверхні тонкої плівки фоторезисту майже не змінюється при проведенні термічних обробок.

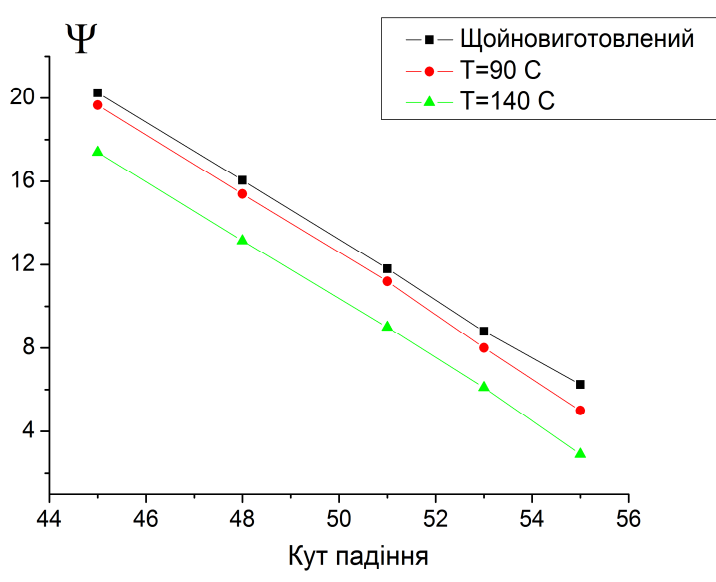

a)

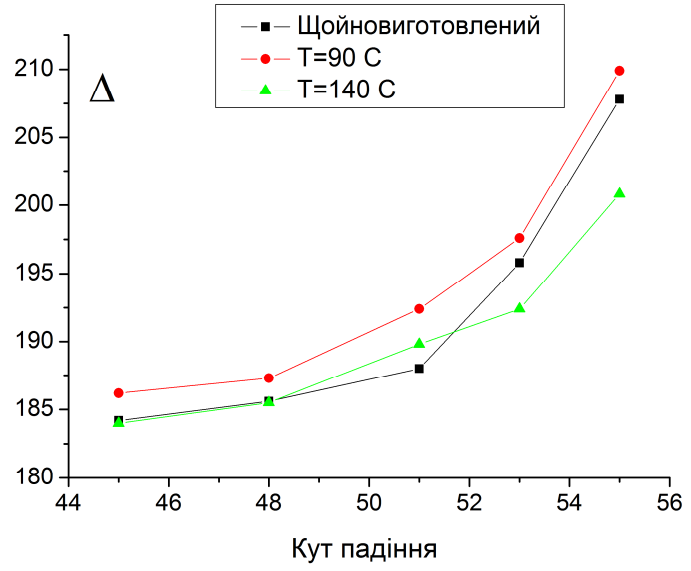

б)

Рис. 2. Еліпсометричні параметри $\Psi$ (а) і $\Delta$ (б) тонкої плівки ФР

Недоліком зазначеного зразка $є$ те, що при проведені термічних відпалів навіть при невеликих температурах спостерігається значне зменшення товщини тонкої плівки (табл. 2). Так, при проведені відпалу при $T=90{ }^{\circ} \mathrm{C}$ товщина тонкої плівки зменшується на $15 \%$, а при проведені відпалу при $T=140{ }^{\circ} \mathrm{C}$ iї товщина зменшується на $35 \%$ порівняно з вихідним станом. Можна зробити висновок, що термічний відпал плівок фоторезисту може суттєво впливати на кінцевий результат при проведені лазерного запису і термічної літографії, що ще раз підтверджує актуальність пошуку відповідного органічного барвника, який може прийти йому на заміну.

Таблиця 2. Геометричні і оптичні властивості тонких плівок барвників

\begin{tabular}{|c|c|c|c|c|c|c|}
\hline \multirow[t]{2}{*}{$\overline{\text { Барвник }}$} & \multicolumn{2}{|c|}{ Свіжий } & \multicolumn{2}{|c|}{$\begin{array}{c}\text { Термічно оброблений при } \\
T=90^{\circ} \mathrm{C} \\
\end{array}$} & \multicolumn{2}{|c|}{$\begin{array}{c}\text { Термічно оброблений при } \\
T=140{ }^{\circ} \mathrm{C} \\
\end{array}$} \\
\hline & $\begin{array}{c}\text { Показник } \\
\text { заломлення }\end{array}$ & $\begin{array}{c}\text { Товщина, } \\
\text { нм } \\
\end{array}$ & $\begin{array}{c}\text { Показник } \\
\text { заломлення } \\
\end{array}$ & $\begin{array}{c}\text { Товщина, } \\
\text { нм } \\
\end{array}$ & $\begin{array}{c}\text { Показник } \\
\text { заломлення }\end{array}$ & $\begin{array}{c}\text { Товщина, } \\
\text { нм } \\
\end{array}$ \\
\hline$\Phi P$ & 1.60 & 62 & 1.62 & 53 & 1.65 & 40 \\
\hline KS-65 & 1.55 & 165 & 1.58 & 153 & 1.6 & 125 \\
\hline K7-1 & 1.67 & 143 & 1.70 & 141 & 1.70 & 137 \\
\hline KT-11 & 1.6 & 172 & 1.62 & 143 & 1.63 & 112 \\
\hline KT-12 & 1.52 & 161 & 1.60 & 160 & 1.63 & 151 \\
\hline
\end{tabular}

На рис. 3 представлено еліпсометричні дані для зразків тонкої плівки органічного барвника KS-65. Аналогічно до зразка фоторезисту кутові залежності азиму- 
ту відновленої лінійної поляризації можуть бути апроксимовані лінійними функціями $y=k \cdot x+b$. Але, на відміну від тонких плівок фоторезисту, для зразків барвника KS-65 характерна трохи інша поведінка залежностей Ч. Рівень цих кривих поступово підвищується завдяки термічним обробкам. Зазвичай така поведінка пов'язана зі зростанням шорсткості поверхні, що викликано ії структуруванням i початком процесів кристалізації.

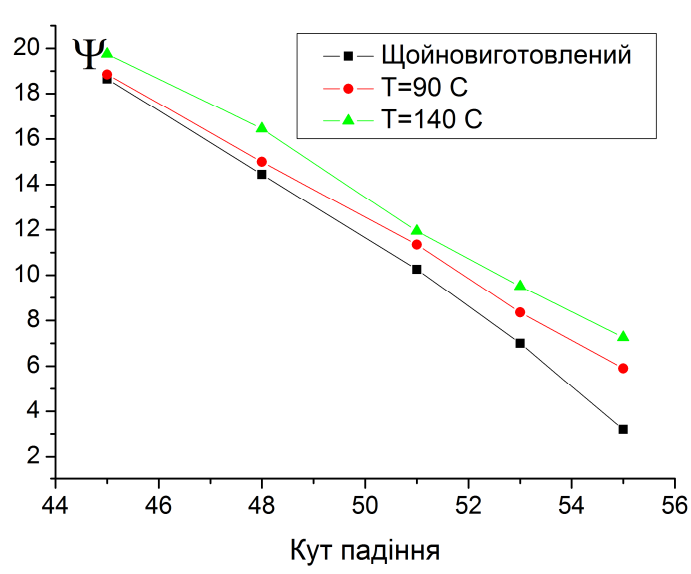

a)

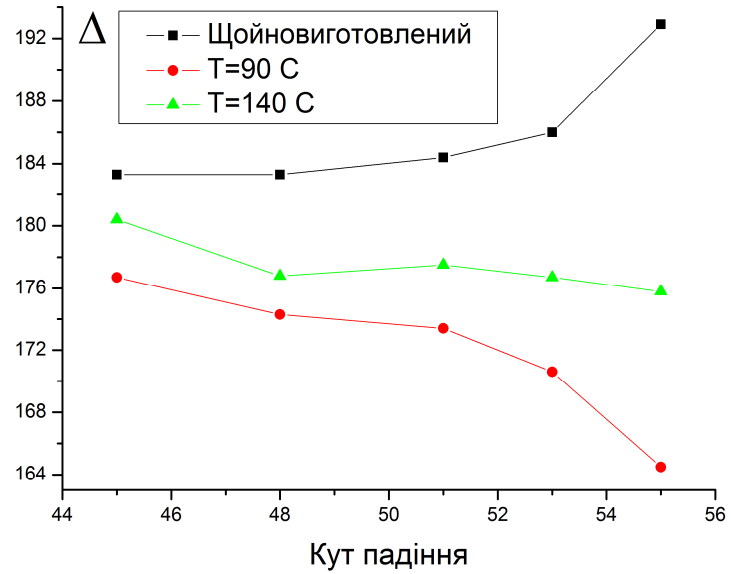

б)

Рис. 3. Еліпсометричні параметри $\Psi$ (а) і $\Delta$ (б) тонкої плівки KS-65

Окремої уваги заслуговує поведінка залежностей $\Delta$ від кута падіння світла. 3 рис. 3 видно, що при термічних обробках змінюється їхній характер, що полягає у суттєвій зміні рівня, на якому розташована крива, та вигін кривої стає протилежним до вихідного стану. Причому, виходячи з наведених даних, можна також зробити висновок, що після обробок при $T=140{ }^{\circ} \mathrm{C}$ характер залежності $\Psi$ змінюється знову, при цьому він наближується до такого, що притаманний вихідному станові. Це може бути пов'язано з початком процесів релаксації, параметри якого нажаль не можна встановити без проведення додаткових досліджень. Зазначимо, що зміна товщини зразків при термічній обробці при $T=90{ }^{\circ} \mathrm{C} \epsilon$ незначною і стає суттєво помітною лише після обробки при температурі $T=140{ }^{\circ} \mathrm{C}$. При цьому зміна товщини складає близько 25 \% порівняно з вихідним станом. 3 огляду на проведений аналіз можна зазначити, що цей зразок більш прийнятний для технологічних процесів, що відбуваються при підвищених температурах, аніж тонка плівка фоторезисту.

На рис. 4 представлено еліпсометричні дані для зразків тонкої плівки металоорганічної сполуки К7-1. Цей зразок заслуговує на увагу за наступними причинами: а) обидві кутові залежності $\Psi$ і $\Delta$ можна апроксимувати лінійними залежностями; б) ані характер залежностей, ані їхні числові значення не змінюються після термічних відпалів в обох режимах. Останній факт означає високу оптичну стабільність і морфологічну стійкість указаної тонкої плівки органічного барвника. Розв'язок оберненої задачі еліпсометрії для зразка К7-1 дає дуже близькі величини товщини плівок як у вихідному стані, так і у станах після термічних обробок. При цьому максимальна відносна зміна товщини зразка не перевищує величини у 
5 \%. На думку авторів - це дуже добрий результат, а сам зразок тонкої плівки К7-1 є прийнятним для технологічних процесів, що відбуваються при підвищених температурах.

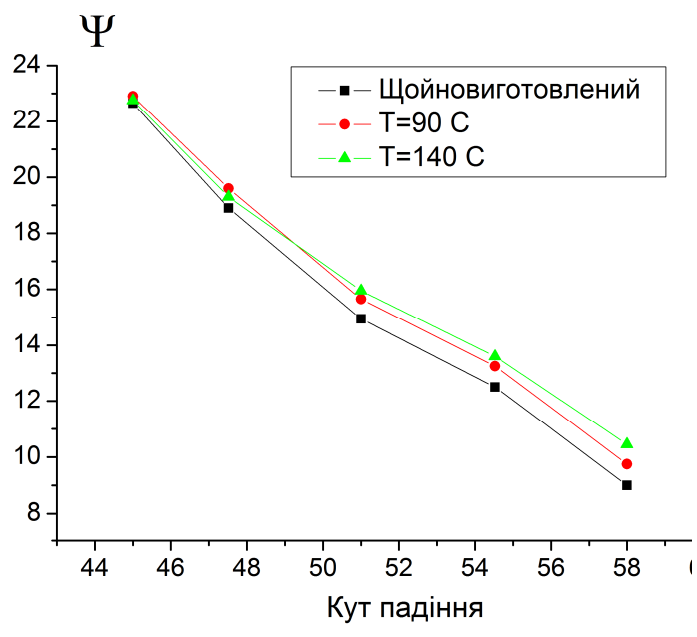

a)

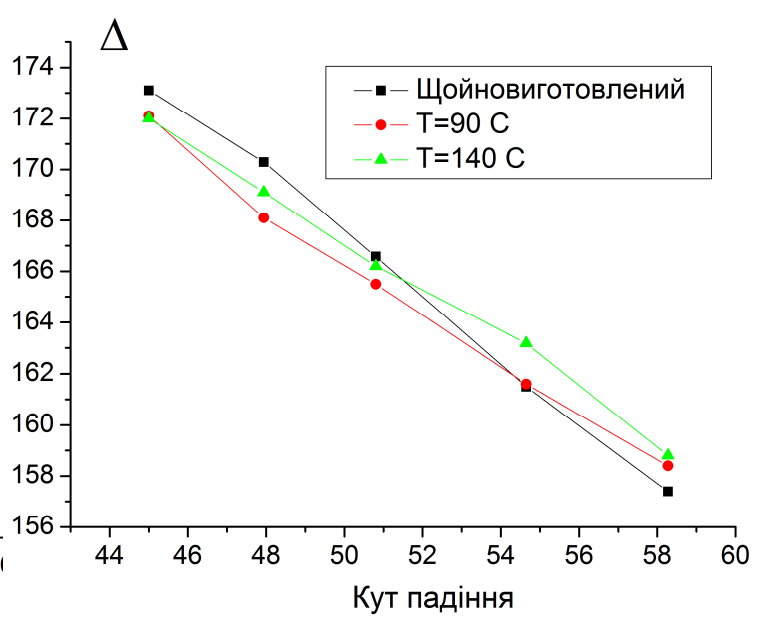

б)

Рис. 4. Еліпсометричні параметри $\Psi$ (а) і $\Delta$ (б) тонкої плівки металоорганічної сполуки К7-1

На рис. 5 представлено еліпсометричні дані для зразків тонкої плівки органічного барвника КТ-11. Поведінка кутових залежностей Ч є схожою до поведінки кутових залежностей для $\Psi$ у випадку вже проаналізованих тонких плівок. Але особливістю саме цього зразка $є$ те, що зміна рівня кривих відбувається при температурі відпалу $T=90{ }^{\circ} \mathrm{C}$ і залишається майже незмінною при подальших термічних обробках. 3 іншого боку, характер кутової залежності $\Delta$ кардинально змінюється як після відпалу при $T=90^{\circ} \mathrm{C}$, так і після відпалу при $T=140{ }^{\circ} \mathrm{C}$. Це вказує на те, що процеси структурування поверхні зразка $є$ необоротними і визначальними вже при термічних обробках при $T=90^{\circ} \mathrm{C}$ і лише незначно корегуються при термічних обробках при $T=140{ }^{\circ} \mathrm{C}$. При цьому відбувається значна зміна товщини тонкої плівки. Так, при температурі відпалу $T=90{ }^{\circ} \mathrm{C}$ товщина тонкої плівки зменшується на $17 \%$, а при температурі відпалу $T=140{ }^{\circ} \mathrm{C}$ iї товщина зменшується майже вдвічі (45\%). Таким чином, цей зразок є найбільш чутливим для технологічних процесів, за яких відбувається термічна обробка.

На рис. 6 представлено еліпсометричні дані для зразків тонкої плівки органічного барвника КТ-12. 3 рисунка видно вже типову поведінку кутової залежності для $\Psi$. Можна лише зазначити незначну зміну рівня $\Psi$ у випадку зразка після термічного відпалу при $T=140{ }^{\circ} \mathrm{C}$. Характер кутової залежності $\Delta$ зазнає змін при термічному відпалі при $T=90{ }^{\circ} \mathrm{C}$ і змінює поведінку після відпалу при $T=$ $=140{ }^{\circ} \mathrm{C}$. Це означає, що для необоротної зміни морфології зразка необхідно проводити відпали при підвищених температурах, а з іншого боку даний барвник $\epsilon$ цілком придатний для технологічних процесів при температурах, що не перевищують $T=90{ }^{\circ} \mathrm{C}$. При цьому зменшення товщини при $T=90^{\circ} \mathrm{C}$ знаходиться у межах похибки вимірювання, лише має місце незначна зміна оптичних властивостей. 


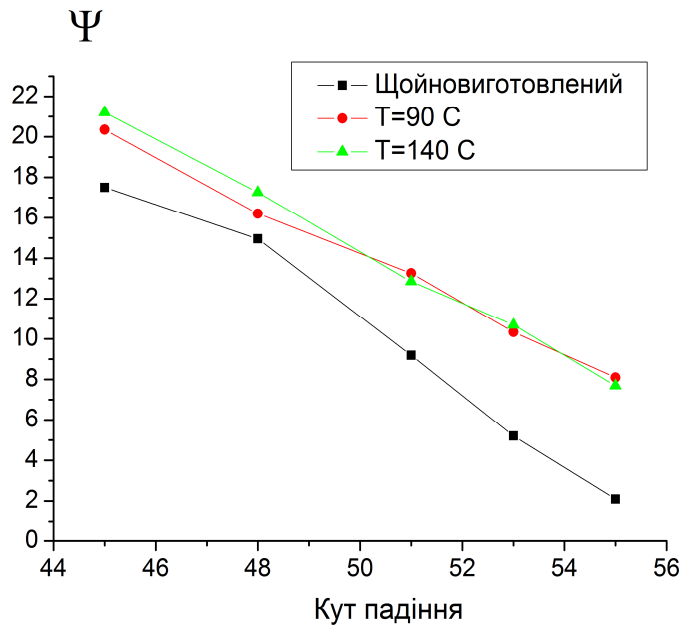

a)

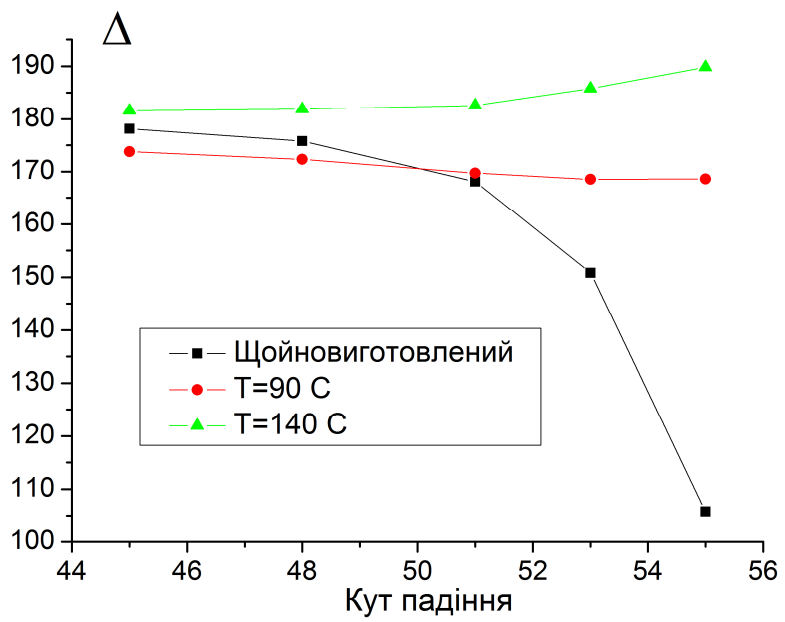

б)

Рис. 5. Еліпсометричні параметри $\Psi$ (а) і $\Delta$ (б) тонкої плівки КТ-11

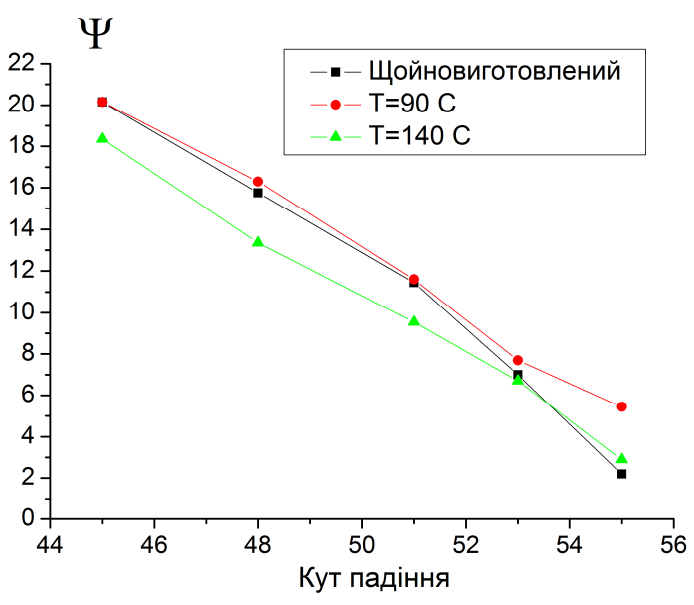

a)

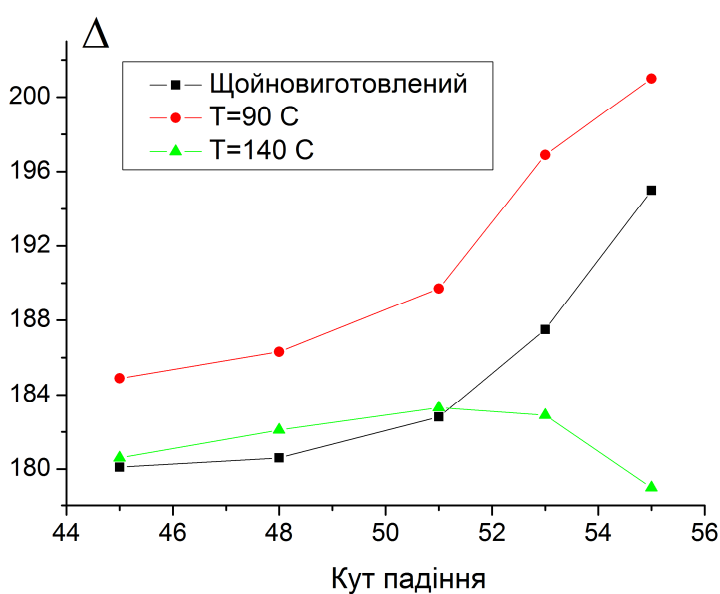

б)

Рис. 6. Еліпсометричні параметри $\Psi$ (а) і $\Delta$ (б) тонкої плівки КТ-12.

Незначна зміна товщини тонких плівок органічного барвника КТ-12 становить приблизно $5 \%$ і має місце лише після термічної обробки при $T=140{ }^{\circ} \mathrm{C}$. На думку авторів, цей зразок є придатним для технологічних процесів, при яких відбувається термічна обробка, що характеризується температурою не більше за $90{ }^{\circ} \mathrm{C}$.

\section{Висновки}

1. Методом центрифугування було отримано композитні плівки органічний барвник - полімер. Показано, що зразки на базі фоторезисту характеризуються більшою селективністю та інтенсивністю поглинання на довжині хвилі 405 нм.

2. Досліджено вплив термічного відпалу на мікроструктуру і оптичні властивості виготовлених композитних плівок залежно від температури відпалу. Показано, що підвищення температури термообробки призводить до зниження кіль- 
кості органічного компонента, також відбувається структурна перебудова поверхні барвника разом з його структурним упорядкуванням. Ці два ефекти призводять до збільшення показника заломлення і зменшення товщини покриття одночасно. При цьому спостерігається зменшення інтенсивності поглинання

3. Для термолітографічного запису запропоновано використовувати композитні плівки, оптичні характеристики яких не зазнають суттєвих змін під впливом термічного відпалу.

1. Petrov V.V. Using ion beams for creation of nanostructures on the surface of high-stable materials / V.V. Petrov, A.A. Kryuchyn, I.V. Gorbov // Semiconductor Physics, Quantum Electronics \& Optoelectronics. - 2007. - Vol. 10, N 1. - P. 27-29.

2. Optimization of $\mathrm{Ge}-\mathrm{Sb}-\mathrm{Sn}-\mathrm{O}$ films for thermal lithography of submicron structures / Jh. Chen, J. Lin, J. Chen, K. Chiu // Japanese Journal of Applied Physics. — 2012. — N 51. — P. 06FC03-1-06FC03-6.

3. Optical characterization and blu-ray recording properties of metal(II)-azo barbituric acid complex films / X.Y. Li, Y.Q. Wu, D.D. Gu, F.X. Gan // Materials Science and Engineering B. - 2009. - N 158. - P. 53-57.

4. Optical recording media based on nanoparticles for superhigh density information storage / K. Grytsenko, O. Belyaev, A. Kryuchin [et al.] // Optical Memory and Neural Networks. - 2013. - Vol. 22, N 3. - P. 127-134.

5. Substrate-induced self-assembly of donor-acceptor type compounds with terminal thiocarbonyl groups / O. Dimitriev, K. Grytsenko, P. Lytvyn [et al.] // TSF. - 2013. N 539. — P. 127 - 133.

6. The influence of temperature on optical properties of merocyanine dye thin films / M.M. Sieryk, T.P. Doroshenko, K.P. Grytsenko [et al.] // Semiconductor Physics, Quantum Electronics \& Optoelectronics. — 2013. - Vol. 16, N 1. - P. 91-96.

7. Spectral, thermal and optical properties of metal(II)-azo complexes for optical recording media / X. Li, Y. Wu, D. Gu, F. Gan // Dyes and Pygments. — 2010. — N 86. — P. 182-189.

8. Патент України МПК G 11B7/24, В 32B3/02. Споосіб виготовлення фоточутливого матеріалу для оптичного запису / В.В. Петров, А.А. Крючин, І.В. Горбов, Ю.О. Бородін, Ю.Л. Брикс, В.В. Курдюков, Ю.Л. Сломинський, О.І. Толмачов, К.П. Гриценко, Ю.В. Коломзаров, заявники: Ін-т проблем реєстрації інформації НАН України, Ін-т органічної хімії НАН України. - № а201400846; заявл. 30.01.2014.

9. Triolo C. Pure optical nano-writing on light-switchable spiropyrans/merocyanine thin film / C. Triolo, S. Patanè, M. Mazzeo [et al.] // Optics Express. — 2014. — Vol. 22, N 1. — P. 283-288.

10. Busnaina A. Nanomanufacturing Handbook / Ahmed Busnaina. - Boca Raton: CRC Press, 2006. $-432 \mathrm{p}$.

11. Baraton M.I. Functional Gradient Materials and Surface Layers Prepared by Fine Particles Technology / Marie-Isabelle Baraton, Irina V. Uvarova. - Berlin: Springer Science \& Business Media, 2001. - $317 \mathrm{p}$.

12. Raju N.V.S. Optimization methods for engineers / N.V.S. Raju. - Amsterdam: PHI Learning Pvt. Ltd., 2014. — 616 p.

13. Effects of post-thermal annealing on the optical constants of $\mathrm{ZnO}$ thin film / S.W. Xuea, X.T. Zua, W.L. Zhouc [et al.] // Journal of Alloys and Compounds. — 2008. — Vol. 448. — P. 21-26. 